\title{
AN ATTORNEY'S PERSPECTIVE ON EMERGING NEW VENTURE OPPORTUNITIES FOR PETROLEUM PROJECTS IN LATIN AMERICA
}

\author{
JAY G. MARTIN
}

This article discusses the potential for new opportunities in the petroleum industry in Latin American countries. The author states that investment in Latin American petroleum projects is required in order to meet energy needs and environmental requirements. After surveying the history, politics and investment climate in Latin America, the author discusses the investment opportunities that have arisen in Latin America as well as the potential risks associated with these investments. He then discusses environmental concerns and other recent developments that impact on petroleum investments. The author examines key issues arising out of petroleum agreements between investors and Latin American governments and outlines the various petroleum agreements currently in use. To conclude, the author discusses the role of legal advisors in assisting clients in making successful investments in Latin American petroleum projects.

\section{TABLE OF CONTENTS}

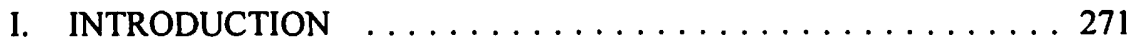

II. AVAILABLE PETROLEUM RESOURCE BASE

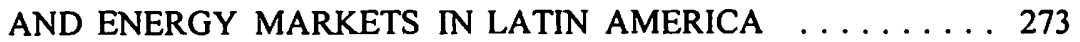

A. PRIMARY ENERGY SUPPLY IN

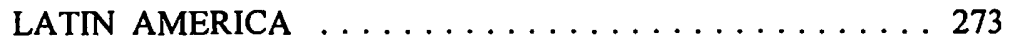

III. GENERAL INVESTMENT CLIMATE

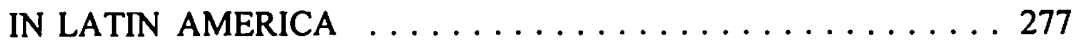

A. INTRODUCTION .................. 277

B. THE CALVO DOCTRINE . . . . . . . . . . . 278

C. CHANGING POLITICAL ENVIRONMENT

IN LATIN AMERICA . . . . . . . . . . . . . . . 279

D. HISTORY OF EXPROPRIATION OF PETROLEUM

PROPERTIES IN LATIN AMERICA . . . . . . . . . 279

IV. IMPORTANT CURRENT POLICY ISSUES

IMPACTING PETROLEUM INDUSTRY

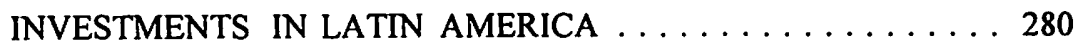

A. PRIVATIZATION AND

B. INVESTMENT REQUIREMENTS FOR
PETROLEUM IN LATIN AMERICA $\ldots \ldots \ldots \ldots \ldots \ldots 281$

C. REGIONAL COOPERATION IN

LATIN AMERICA REGARDING

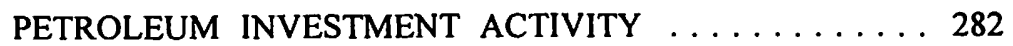

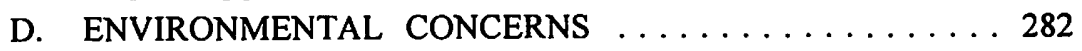

V. RECENT DEVELOPMENTS IN LATIN AMERICA

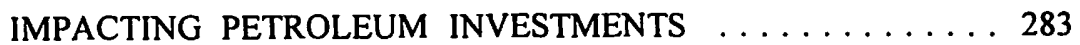

VI. LEGAL FRAMEWORK FOR UPSTREAM

PETROLEUM INVESTMENTS IN LATIN AMERICA . . . . 286

Assistant General Counsel, Mobil Oil Corporation, Fairfax, Virginia. 
VII. REVIEW OF KEY ISSUES IN PETROLEUM

AGREEMENTS WITH LATIN AMERICAN

FOREIGN HOST GOVERNMENTS $\ldots \ldots \ldots \ldots \ldots \ldots \ldots 287$

A. FISCAL AND OPERATIONAL ISSUES $\ldots \ldots \ldots \ldots 287$

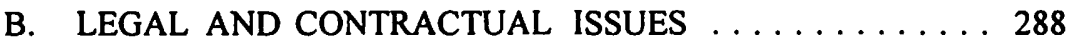

VIII. A PETROLEUM COMPANY'S ENTRY INTO

INTERNATIONAL OPERATIONS: INTERNAL PHASE $\ldots \ldots 290$

IX. OVERVIEW OF TYPES OF INTERNATIONAL

PETROLEUM EXPLORATION AND DEVELOPMENT

AGREEMENTS CURRENTLY IN USE IN PETROLEUM

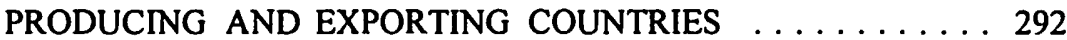

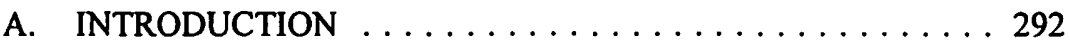

B. SPECIFIC TYPES OF INTERNATIONAL

EXPLORATION AGREEMENTS . . . . . . . . . 293

X. THE ROLE OF LEGAL ADVISORS IN ASSISTING

INTERNATIONAL PETROLEUM COMPANIES IN

MAKING SUCCESSFUL FOREIGN INVESTMENTS

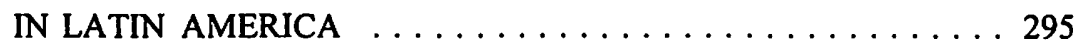

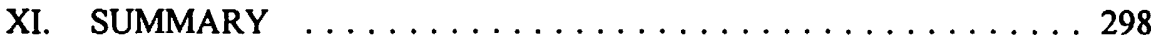

\section{INTRODUCTION}

There has been an international component to the U.S. petroleum industry almost from the very beginning of the industry. Until recently, however, the international petroleum industry was generally an adjunct to the domestic business of a few relatively major petroleum companies due to the significantly greater risks and capital requirements inherent in international business. The risks inherent in the international petroleum industry were vividly demonstrated in the 1960s and 1970s with the nationalization of private petroleum industry assets in a number of foreign countries. However, the early 1980s witnessed a torrent of international crude oil and natural gas activity, with major U.S. petroleum companies shifting the focus of their exploration programs to the international scene and even some of the smallest U.S. petroleum independents moving aggressively into the international arena.

The genesis of this renewed international emphasis in the petroleum industry includes elements of the following: the maturing of the U.S. petroleum industry with diminished exploration opportunities in the easily accessible onshore lower forty-eight states; the opening of many new areas for petroleum exploration, notably China and much more recently eastern Europe, and the countries which comprised the former Soviet Union; the passage of time since the rash of petroleum nationalizations and the international safeguards introduced into exploration agreements; the relatively lower costs and significantly higher potential remaining reserves of the international petroleum industry; and the continuing relatively high demand for crude oil. Today, even with the current low crude oil prices, the petroleum industry is trying to cope with the challenge of rapid international expansion. 
In the years ahead, the petroleum industry in Latin America will require much higher levels of investment than in the recent past to meet both energy needs and environmental requirements. Moreover, many of the petroleum producing countries in Latin America are currently in an economic bind. Populations are growing rapidly. When combined with flat crude oil prices, the result is declining real per capita income. The OPEC surpluses, which so worried central bankers in the 1970s, have long since disappeared. In addition, most Latin American countries face significant debt burden and balance-of-payment pressures.

Like many other governments around the world, Latin American governments need to significantly reduce government spending and deficits. Yet they face significant political difficulties in making such adjustments pertaining to historical obligations of the state to employ large numbers of people and the historic domestic control of the prices for refined crude oil products such as motor oil and gasoline at artificially low levels. In addition, state petroleum companies in Latin America have to compete with all manner of popular social programs including education, medicine, welfare, unemployment relief and state pensions. Accordingly, the cost of running these stateowned petroleum companies is very high. In a world in which crude oil prices are not even keeping pace with inflation, crude oil earnings can be increased only through greater productivity and increased output. But that takes significant investment money that Latin American petroleum exporting countries generally do not have.

Thus economic imperatives and changing ideologies are moving current would-be petroleum exporting countries in Latin America to more aggressively seek the international petroleum industry's capital, technology and management skills. A growing number of Latin American countries are showing a new willingness to transfer the risk of exploration and the investment requirements to an international petroleum industry that is organized to effectively and efficiently carry such risks and that has the capital - thus preserving limited state funds for investment in infrastructure and societal needs.

Overall, it seems probable that state-owned petroleum companies will control a substantially smaller share of the Latin American petroleum business in the future than they have in the past. The reality is that Latin American governments that wish to stimulate economic growth and compete successfully for scarce capital funds and the best available technology will develop institutions which uphold contracts, allow for the resolution of disputes on commercial rather than political grounds that deliver a convertible currency, allow reasonable returns to petroleum companies, implement world class investments and are prepared to take risks, all within a predictable fiscal system and stable transparent legal system.

With such institutions in place, international capital will seek out profitable investments. The conduits will likely be domestic state-owned petroleum firms in Latin America with strong local market positions that can form a platform for further domestic and international petroleum growth and international firms wishing to expand their activities into new markets. 
New trade agreements (such as the North American Free Trade Agreement' ("NAFTA")) and the development of regional trade organizations in Latin America (such as the Latin American Energy Organization ("OLADE"), the Andean Pact) will no doubt continue to encourage crude oil and natural gas trade across the Americas. It can be expected that this trade will stimulate the development and trade of new crude oil and natural gas supplies and will help the U.S. and Latin American nations to meet their growing energy supply deficits.

\section{AVAILABLE PETROLEUM RESOURCE BASE AND ENERGY MARKETS IN LATIN AMERICA}

\section{A. PRIMARY ENERGY SUPPLY IN LATIN AMERICA}

Despite an uneven distribution across countries, Latin America is well endowed with petroleum reserves. The region (excluding the Caribbean region) comprising Mexico and Central and South America, produces substantially more energy (including petroleum) than it consumes. Total primary energy production for the region in 1993 was approximately 12.8 barrels of oil equivalent per day ("boe/d"), up 4 percent from 12.3 million boe/d in 1990. Most of the primary energy produced in the region is petroleum ( 60 percent), while natural gas ( 16 percent) and other energy ( 13 percent) mainly noncommercial energy (including firewood, cane products and others) and geothermal power - account for the next largest shares. Hydroelectricity (6 percent), coal ( 4.5 percent) and nuclear power ( 0.5 percent) comprise the remaining production shares.

Latin America is a net exporter of crude oil, refined crude oil products and coal. The bulk of the region's primary energy exports is crude oil (of which about 80 percent is crude oil and 20 percent is crude oil products), while coal accounts for a tiny share. Natural gas accounted for over 16 percent of primary energy production in 1993 and virtually all of it was consumed within the region. Bolivia and Mexico are the only countries in Latin America that currently export natural gas. Mexico also imports gas from the U.S. on occasion. Argentina also imports natural gas from time to time.

\section{Crude Oil}

Latin America currently accounts for approximately 12.4 percent of the world's crude oil reserves and 12.1 percent of crude oil production (Table 1). At the end of 1992, proved crude oil reserves in Latin America stood at 123 billion barrels; total regional crude oil production in 1992 was estimated at 7.2 million barrels per day. Crude oil reserves in Latin America are very unevenly distributed.

Together, Mexico and Venezuela account for over 82 percent of the region's 123 billion barrels of crude oil reserves and more than 70 percent of current crude oil 
production, while countries such as Paraguay and Uruguay have no proven crude oil reserves or production.

In addition, Venezuela has approximately 270 billion barrels of recoverable heavy and extra-heavy crude oil in the Orinoco Tar Belt that could eventually be exported as synthetic crude oil or as Orimulsion, a boiler fuel made of a mixture of bitumen and water. Mexico and Venezuela are by far the region's largest exporters of crude oil and crude oil products. At its 1992 level, Latin American crude production could continue for about forty-seven years, which is slightly higher than the world average reserves/production ratio of forty-six years.

Latin America has been a net crude oil-exporting region throughout the past two decades. For example, in 1993, Latin America and the Caribbean exported a total of 3.4 million barrels per day of petroleum including 2.69 million barrels per day of crude oil.

Table 1. Oil Reserves and Production in Selected Latin American Countries

\begin{tabular}{|c|c|c|c|c|c|}
\hline & \multicolumn{2}{|c|}{ Reserves $1992^{\circ}$} & \multicolumn{2}{|c|}{ Production 1992} & \multirow[b]{2}{*}{$\begin{array}{c}\text { Reserves/ } \\
\text { Production Ratio } \\
\text { Years }\end{array}$} \\
\hline & $\begin{array}{l}\text { Million } \\
\text { Barrels }\end{array}$ & $\begin{array}{l}\text { Share in } \\
\text { the Region }\end{array}$ & $\begin{array}{c}\text { Thousand } \\
\text { Barrels per } \\
\text { Day }\end{array}$ & $\begin{array}{l}\text { Share in } \\
\text { the Region }\end{array}$ & \\
\hline Venezuela & 62,650 & $41.5 \%$ & 2,329 & $32.2 \%$ & 74 \\
\hline Mexico & 52,298 & $40.6 \%$ & 2,776 & $38.3 \%$ & 51 \\
\hline Brazil & 3,600 & $2.9 \%$ & 641 & $8.9 \%$ & 15 \\
\hline Columbia & 1,935 & $1.6 \%$ & 454 & $6.3 \%$ & 12 \\
\hline Ecuador & 1,600 & $1.3 \%$ & 322 & $4.5 \%$ & 14 \\
\hline Argentina & 1,570 & $1.3 \%$ & 555 & $7.7 \%$ & 8 \\
\hline Peru & 381 & $0.3 \%$ & 116 & $1.6 \%$ & 9 \\
\hline Chile & 300 & $0.2 \%$ & 15 & $0.2 \%$ & 55 \\
\hline Bolivia & 112 & $0.1 \%$ & 21 & $0.3 \%$ & 14 \\
\hline Others". & 256 & $0.2 \%$ & 10 & $0.1 \%$ & 69 \\
\hline Latin Amcrica & 123,702 & $100.0 \%$ & 7,239 & $100.0 \%$ & 47 \\
\hline The Caribbean & 678 & & 155 & & 12 \\
\hline World Total & 997,042 & & 60,029 & & 46 \\
\hline
\end{tabular}




\begin{tabular}{|c|c|c|c|c|c|}
\hline & \multicolumn{2}{|c|}{ Reserves $1992^{\circ}$} & \multicolumn{2}{|c|}{ Production 1992} & \multirow[b]{2}{*}{$\begin{array}{c}\text { Reserves/ } \\
\text { Production Ratio } \\
\text { Years }\end{array}$} \\
\hline & $\begin{array}{l}\text { Million } \\
\text { Barrels }\end{array}$ & $\begin{array}{l}\text { Share in } \\
\text { the Region }\end{array}$ & $\begin{array}{c}\text { Thousand } \\
\text { Barrels per } \\
\text { Day }\end{array}$ & $\begin{array}{l}\text { Share in } \\
\text { the Region }\end{array}$ & \\
\hline $\begin{array}{l}\text { Share of Latin } \\
\text { American in } \\
\text { World Total }\end{array}$ & & $12.4 \%$ & & $12.1 \%$ & \\
\hline
\end{tabular}

End of the year.

• Guatemala's crude oil reserves increased significantly from 35 million barrels in late 1991 to 207 million in late 1992.

Sources: Oil \& Gas Journal and East-West Center Data File.

\section{Natural Gas}

At the end of 1992, Latin America's 250 trillion cubic feet of gas accounted for approximately 5.1 percent of the world's total known natural gas reserves (Table 2). Latin America's commercialized gas production in 1992 totalled 8.7 billion cubic feet per day, representing 4.2 percent of the world's total natural gas output. Venezuela, Mexico and Argentina account for nearly 88 percent of the region's natural gas reserves and approximately 78 percent of natural gas production. Venezuela, Mexico and Argentina will continue to be major natural gas producers in the 1990s, while Bolivia's share in the regional natural gas production is likely to increase. Venezuela, Peru and Argentina also have the potential to increase their natural gas output levels. For the rest of the 1990s, natural gas trade should increase as a number of countries in Latin America are developing their natural gas reserves for export. Bolivia has just reached an agreement with Brazil to supply natural gas to the latter for twenty years, beginning in 1995. In the meantime, negotiations on an agreement for Chile to import natural gas from Argentina are progressing. In addition, several other Latin American countries plan to increase gas consumption in order to conserve oil for export as well as reduce pollution. The expected increase in natural gas use will change the energy consumption picture. Venezuela and Peru both have large untapped natural gas reserves but both countries are facing significant political, legal and financial difficulties in developing such resources. In addition, the government of Colombia has adopted a market-oriented natural gas policy that could result in accelerated development of gas reserves.

In all but a few countries in Latin America, natural gas is currently a substantially underutilized resource. Natural gas constituted about 28 percent of the region's hydrocarbons reserves (oil and gas) in 1991 but it accounted for only 20 percent of total hydrocarbons production, compared to 80 percent for petroleum. The current ratio of proven reserves to production for natural gas in 1992 (gas reserves/commercialized gas production level) ranged from 509 years for Ecuador, 156 years for Venezuela and 152 years for Peru to thirty-eight years for Bolivia and thirty-six years for Argentina, with an average of seventy-nine years for the region. Comparatively, the reserves/production ratio for crude oil is, on average, about forty-six years for the region. While crude oil 
provided 52 percent of primary energy consumption, natural gas contributed only 17 percent of the total. Per capita consumption of natural gas in the region as a whole is less than the world average and far lower than most industrialized countries. The Latin American region thus has great potential to increase natural gas production as well as consumption. ${ }^{2}$

In 1991, the Latin American domestic natural gas supply amounted to 1.8 million boe/d, of which about 48 percent was fed into refineries, power plants and natural gas treatment plants and 36 percent was directly consumed by end users. The rest of the natural gas produced was flared, reinjected or lost. Industry comprised the bulk of direct gas consumption in the region, accounting for 76 percent of the total, followed by the residential (19 percent) and commercial and public service sectors (4 percent).

International trade of natural gas in Latin America is still limited to a few countries; Argentina and Mexico are the only importers of natural gas and Bolivia and Mexico are the only exporters. The existing international pipelines include the U.S.-Mexico pipelines with a combined capacity of 954 million cubic feet per day and the BoliviaArgentina pipeline with a capacity of 390 million cubic feet per day.

Table 2. Gas Reserves and Production in Selected Latin American Countries

\begin{tabular}{|c|c|c|c|c|c|}
\hline \multirow[b]{2}{*}{ Country } & \multicolumn{2}{|c|}{ Reserves 1992* } & \multicolumn{2}{|c|}{ Production 1992} & \multirow[b]{2}{*}{$\begin{array}{c}\text { Reserves/ } \\
\text { Production } \\
\text { Ratio } \\
\text { (Years) }\end{array}$} \\
\hline & $\begin{array}{c}\text { Billion } \\
\text { Cubic Feet }\end{array}$ & $\begin{array}{l}\text { Share } \\
\text { in the } \\
\text { Region }\end{array}$ & $\begin{array}{c}\text { Million } \\
\text { Cubic Feet } \\
\text { per Day }\end{array}$ & $\begin{array}{c}\text { Share in } \\
\text { the } \\
\text { Region }\end{array}$ & \\
\hline Venezuela & 126,492 & $50.5 \%$ & 2,221 & $25.5 \%$ & 156 \\
\hline Mexico & 70,900 & $28.3 \%$ & 3,593 & $41.2 \%$ & 54 \\
\hline Argentina & 22,700 & $9.1 \%$ & 1,661 & $19.0 \%$ & 37 \\
\hline Colombia & 7,200 & $2.9 \%$ & 395 & $4.5 \%$ & 50 \\
\hline Peru & 7,054 & $2.8 \%$ & 127 & $1.5 \%$ & 152 \\
\hline Brazil & 4,400 & $1.8 \%$ & 302 & $3.5 \%$ & 40 \\
\hline Bolivia & 4,108 & $1.6 \%$ & 295 & $3.4 \%$ & 38 \\
\hline Chile & 3,900 & $1.6 \%$ & 103 & $1.2 \%$ & 103 \\
\hline
\end{tabular}

2 See J. Culver-Hopper, "Natural Gas: Outlook for Latin American/Caribbean Energy Markets in the 1990s" in Program on Resources: Energy and Minerals (East-West Center, Honolulu, Hawaii, 1992). 


\begin{tabular}{|c|c|c|c|c|c|}
\hline & \multicolumn{2}{|c|}{ Reserves $1992^{*}$} & \multicolumn{2}{|c|}{ Production 1992} & \\
\hline Country & $\begin{array}{c}\text { Billion } \\
\text { Cubic Feet }\end{array}$ & $\begin{array}{l}\text { Share } \\
\text { in the } \\
\text { Region }\end{array}$ & $\begin{array}{c}\text { Million } \\
\text { Cubic Feet } \\
\text { per Day }\end{array}$ & $\begin{array}{c}\text { Share in } \\
\text { the } \\
\text { Region }\end{array}$ & $\begin{array}{l}\text { Reserves/ } \\
\text { Production } \\
\text { Ratio } \\
\text { (Years) }\end{array}$ \\
\hline Ecuador & 3,899 & $1.6 \%$ & 21 & $0.2 \%$ & 509 \\
\hline Others" & 10 & $0.0 \%$ & 3 & $0.0 \%$ & 10 \\
\hline Latin America & 250,663 & $100.0 \%$ & 8,721 & $100.0 \%$ & 79 \\
\hline The Caribbean & 8,809 & & 526 & & 46 \\
\hline World Total & $4,885,362$ & & 208,811 & & 64 \\
\hline $\begin{array}{l}\text { Share of Latin } \\
\text { American in World } \\
\text { Total }\end{array}$ & & $5.1 \%$ & & $4.2 \%$ & \\
\hline
\end{tabular}

End of the year.

- Commercialized production only, which is part of total gas output.

Sources: Oil \& Gas Journal and East-West Center Data File.

\section{GENERAL INVESTMENT CLIMATE IN LATIN AMERICA}

\section{A. INTRODUCTION}

As a general matter, perceptions of the investment climate in Latin America are much more positive than a few years ago. It is the era of economic and political reform: inflation rates are down; financing is available through various new private sector vehicles including regional investment funds and pension fund investments; governments are floating Eurobonds; stock markets are booming; and privatizations are the order of the day. Latin American governments want foreign investment and many are revising their laws and even their constitutions to make foreign investors feel more welcome than ever before. They are clearly succeeding, as witnessed by the influx of foreign capital and investments in so many forms. American companies are turning to Latin America as an alternative to domestic U.S. investment and indeed as a less risky alternative to some of the other places where petroleum resources are available. Clearly, the risks that were once such a deterrent to foreign investment in Latin America have diminished, at least for the moment.

But against this backdrop it is important to keep in mind both the history of foreign investment in Latin America as well as some other factors that any investor, but particularly one in the petroleum sector in Latin America, should keep in mind in considering the risks as well as the rewards of doing business there. 


\section{B. THE CALVO DOCTRINE}

A significant factor in the history of foreign investment in Latin America and one that is still present to some degree in a number of Latin American jurisdictions, is the Calvo Doctrine. This 19th century doctrine, named after an Argentine jurist, aimed to prevent abuses of diplomatic protection of foreigners by refusing to recognize rights of aliens that are different from, or more extensive than, those of nationals. The Calvo Doctrine encompasses two fundamental principles: first, that sovereign states enjoy the right to freedom from interference from other states; and second, that aliens are not entitled to rights and privileges not accorded to nationals.

In addition to continuing to find expression in some Latin American national constitutions, laws and regulations, the Calvo Doctrine may be reflected in mandatory contractual provisions known as "Calvo clauses", under which a foreign party is deemed a national of the host country for purposes of the contract and the foreign party renounces its right to ask its government to assert diplomatic protection on its behalf in the event of government interference with the foreign national's rights.

These types of provisions are, obviously, inconsistent with international arbitration provisions common in international investment agreements in that they provide that the foreign investor may seek redress only before local authorities, under local law, except where reference to those authorities has resulted in a denial of justice under principles of international law. Thus the investor whose contract contains a Calvo clause cannot look to neutral international arbitration for dispute resolution; instead he or she must exhaust available local remedies, subject to local law. And local judicial fora may lack the authority to overturn actions based on local law, even if those actions or laws contravene rights established by contract or are in violation of applicable international law principles. Under these provisions, so long as the local judicial process does not contravene principles of due process, it is not subject to review in any international forum.

While Calvo Doctrine issues inhibited foreign investment in many Latin American countries during the 1970s following the promulgation of the Andean Investment Pact in 1971, the 1980s saw a gradual softening of Calvo principles in many Latin American countries. The acceptance by Mexico of the NAFTA provisions on investment dispute resolution, under which an investor can seek a remedy either through binding investorstate arbitration or by reference to the host country's domestic courts and under which investors are entitled to treatment in accordance with international law, is an important indication of the decline of the Calvo Doctrine.

Other indicators of movement towards acceptance of international arbitration of investment disputes can be found in the acceptance by Argentina, the birthplace of Calvo himself, of the standard form of U.S. Bilateral Investment Treaty, with dispute resolution procedures similar to those contained in NAFTA. The ratification by a number of Latin American countries of the ACCEDE convention, which provides for international arbitration of investment disputes between investors and states, is further 
indication of the increased receptivity to international dispute resolution procedures by Latin American governments.

Nevertheless, numerous reminders of the sensitivity of Latin American governments to issues of national sovereignty remain and should not be ignored. The new Mexican Foreign Investment Law still refers to the Calvo provision of the Mexican constitution, for example, and Calvo-type clauses, under which foreign investors renounce diplomatic protection and agree to refer disputes to local courts still appear in concession agreements in a number of Latin American countries. While the local legal system may generally be an acceptable forum in which to adjudicate investment disputes, the effect of these clauses is to subject the investor to a legal regime that may not guarantee treatment in accordance with the standards of international law regarding protection of foreign investments.

\section{CHANGING POLITICAL ENVIRONMENT IN LATIN AMERICA}

As political and economic reforms take hold throughout Latin America, at the same time that foreign investment becomes more attractive, some of the rules of the game become less predictable. New constituencies may find their political voices and old practices that were standard operating procedure may suddenly come under challenge. Such changes clearly can create political risks for the unwary.

For example, with the opening of trade and investment among the NAFTA countries and with the eventual expansion of NAFTA to other Latin American countries, environmental standards are being rationalized and made more uniform, with the result that standards in many developing countries are rising. In addition, new voices are being heard, demanding higher environmental standards and holding governments to higher standards of enforcement of existing standards. Thus, some major petrochemical projects have been delayed or indeed abandoned due to unexpected environmental challenges. New environmental controls in Colombia require oilfield developers to look at the environmental effects not just of the individual wells they are drilling and rods they are building, but also at the effect of the development of the whole field on the entire "ecobasin". While this approach cannot be called unreasonable, it clearly has created a higher standard than existed before and is a new risk for a developer to consider.

Similarly, increasingly effective activism on behalf of indigenous populations has caused the rethinking of more than one major petroleum project that would not have had to confront the potential effects of its activities on local populations just a few years ago.

\section{HISTORY OF EXPROPRIATION OF PETROLEUM PROPERTIES IN LATIN AMERICA}

Finally, no discussion of political risk and investment climate in Latin America is complete without acknowledging the history of expropriations of major international investment there during the 1970s. It is relevant to note that during the first five years 
of its existence (1971-75) the Overseas Private Investment Corporation ("OPIC"), the U.S. government's political risk insurance program, processed a total of eighteen expropriation claims, fifteen of which involved investments in Latin America. During the same period, OPIC paid a total of nineteen inconvertibility claims, of which twelve were from Latin American countries and five political violence claims, two of which were from Latin American countries.

While OPIC has long overcome the effects of this early history, it is clear that this experience left an indelible impression on OPIC, as the political events that gave rise to these claims occurred just as the agency was being created.

\section{IMPORTANT CURRENT POLICY ISSUES IMPACTING PETROLEUM INDUSTRY INVESTMENTS IN LATIN AMERICA}

As economic recovery continues in Latin America, all Latin American countries face growing demand for energy sources. The governments in the region have to use the limited capital available to them efficiently in order to achieve their targets of energy and economic development and must effectively attract significant amounts of foreign and private investment to provide additional funding required to achieve these goals. Some of the most important policy issues in the Latin American petroleum sector are briefly discussed below.

\section{A. PRIVATIZATION AND DEMONOPOLIZATION}

Until recently, the petroleum exploration and production sector in many Latin American countries was largely closed to private and foreign investment under hydrocarbon laws or by constitution, as in Mexico, Brazil, Venezuela and Ecuador. Over the past few years, in efforts to reduce costs and increase efficiency, numerous state petroleum companies in Latin America have been undergoing substantial reorganizations, which include downsizing, demonopolization and privatization. ${ }^{3}$ Pemex, the giant Mexican state-owned petroleum company, which was ranked first in the number of employees and third in crude oil production among the state-owned petroleum companies in the world in 1990, began its painful but necessary restructuring in 1991 in order to downsize its staff and become more efficient. Also in 1991, Peru eliminated the monopoly of its state-owned petroleum company, Petroperu, by instituting policies that included offering small refineries for sale and granting more concessions to foreign and private petroleum companies, especially for upstream crude oil development. PDVSA, Venezuela's state-owned petroleum company, has begun the process of demonopolizing its upstream crude oil and natural gas activities by opening up the development of marginal fields to private participation.

J. Culver-Hopper et al., "Investment Opportunities and Financing Issues in the Latin American/Caribbean Hydrocarbons Sector" in Latin American/Caribbean Oil and Gas Report Series No. 2, Program on Resources: Energy and Minerals (East-West Center, Honolulu, Hawaii, 1992) at 3. 
An important complement to the reorganizations of state-owned petroleum companies in various Latin American countries is the reduction of domestic subsidies for crude oil refined products. Both Venezuela and Ecuador, the countries with the heaviest product subsidies, have been implementing measures to reduce such subsidies; however, these initiatives have met with great resistance. Other countries, such as Chile and Bolivia, have been able to successfully reduce or totally eliminate petroleum product subsidies.

Thus far, Argentina has been the strongest advocate for privatization of the state petroleum sector in Latin America. Argentina began in 1991 to privatize the assets of its state-owned petroleum company, YPF and state-owned natural gas company, Gas del Estado. YPF's share of domestic crude oil production has been reduced from 70 percent to about 40 percent since 1991. In late 1992, Argentina sold off Gas del Estado to private and foreign investors. If Argentina's bold push for privatization is successful it will offer important lessons for other Latin American countries' state-owned petroleum companies.

\section{B. INVESTMENT REQUIREMENTS FOR PETROLEUM IN LATIN AMERICA}

Substantial investment in all areas of the Latin American petroleum industry is needed. Large producers such as Mexico, Venezuela and Brazil need tremendous amounts of investment to maintain or increase their crude oil and natural gas production levels. Venezuela and Brazil in particular have the potential to substantially increase their crude oil reserves and thus need sufficient funds for upstream exploration. Medium-sized crude oil producers in the region such as Argentina, Ecuador and Peru are striving to reverse the declining crude oil reserves in their countries and require various levels of investment in the search for new crude oil. Altogether, capital requirements for the modernization and expansion of the crude oil and natural gas sector in Latin America are estimated to be close to US\$120 billion between 1992 and 1996.

The three largest petroleum producers - Mexico, Venezuela and Brazil - comprise approximately 68 percent of the total investment needed. The largest portion of the capital required, at least US\$50 billion, is earmarked for upstream activities to increase oil and gas production capacity. Private investment is estimated to account for about 40 percent of the total for the Latin American region and most of this is expected to be provided by multinational petroleum companies, international banks and foreign and domestic independent petroleum companies. Most of the private investment is expected to flow to the upstream sector and petrochemical industry in the form of direct investment by multinational and foreign and domestic independent petroleum companies.

Given the importance of attracting private/foreign investment to meet the demand for funding, a favourable investment climate needs to be established in Latin America to realize this goal. While governments in many Latin American countries have revised their petroleum order to introduce more foreign capital into their petroleum sector, there are a number of pending issues which are linked with broader political and economic developments in the region. The highly nationalistic constitutions of Mexico and Brazil, 
guerilla activities in Colombia and Peru, recent failed coup attempts in Venezuela, the uncertainty of the economic reforms under the new administration in Brazil, the recent assassination of Mr. Colosio in Mexico and Mexico's recent economic problems triggered by the devaluation of the peso, the fuel price policy dispute in Ecuador and the future continuing development of Argentina's privatization program are some of the many issues that may complicate the climate for foreign investment.

\section{REGIONAL COOPERATION IN LATIN AMERICA REGARDING PETROLEUM INVESTMENT ACTIVITY}

While the 1990s appear to be a promising decade for the petroleum sector in Latin America, many countries in the region are experiencing difficulties in reforming the energy sector and their economies in general. Under these circumstances, regional cooperation has become more attractive as common interest and mutually beneficial trade and investment opportunities are developing throughout the region. In the petroleum sector, organizations such as ARPEL (the association for state-owned petroleum companies in the Western Hemisphere) and OLADE are positioned to play significant roles in promoting energy security and efficiency as centres of technical assistance and information. In addition, associations such as the Andean Pact, the San José Accord and Mercosur are encouraging greater integration of Latin American and Caribbean petroleum markets. The Andean Pact, which includes Venezuela, Colombia, Ecuador, Peru and Bolivia, provides funding for petroleum development projects in some of its member countries through the Andean Development Bank. Through the San José Accord, Venezuela and Mexico have secured crude oil markets in the nine Central American and Caribbean countries, including Costa Rica, El Salvador, Guatemala, Nicaragua, Panama, the Dominican Republic, Barbados, Belize and Jamaica. Mercosur, an organization established to build a common market between Brazil, Argentina, Uruguay and Paraguay, has also addressed petroleum development integration and it is strongly promoting the development of intraregional natural gas trade.

In addition to the multinational organizations, bilateral energy links among Latin American countries are developing rapidly. Venezuela and Colombia have strengthened their ties through the trade of electricity; Bolivia, Brazil, Argentina, Chile, Peru and Paraguay may soon set up a network of natural gas trade links to transport natural gas from gas fields in Argentina, Bolivia and Peru to consuming areas in the other countries.

\section{ENVIRONMENTAL CONCERNS}

An issue of growing importance in Latin America is protection of the environment. Concerns are mounting over the impact of upstream petroleum activities on the natural environment in sensitive jungle and rain forest ecosystems and offshore areas as well as the effects of pollution from stationary (e.g. power plants, refineries, petrochemical plants) and mobile (e.g. motor vehicles) sources. Ecuador recently instituted an environmental tax on crude oil production. 
Of all the Latin American countries, Mexico, which has suffered some of the region's most serious deterioration of environmental quality, has perhaps been the most aggressive in addressing the problems caused by pollution attributable to petroleum operations. The country shut down three highly polluting refineries with capacity totalling 164,000 barrels per day in 1991. Mexico also imports methyl tertiary butyl ether ("MTBE") to reduce the gasoline's lead content and increase the fuel's quality. Brazil and Venezuela are planning to build their own MTBE capacity as part of the overall refinery expansion programs. In August 1990, the state-owned petroleum companies of these two countries signed a mutual cooperation agreement to combat crude oil spills in Venezuelan and Brazilian territorial waters.

Another indication that the Latin American governments are making increased efforts to protect the environment is the projected increase of natural gas use in a number of countries. As regional trade expands, natural gas will become the fastest growing traded energy product in Latin America by the year 2000.

In short, energy policy has a tremendous impact on the development of petroleum production and consumption. While the issues discussed above are shared by many Latin American countries, each individual country in the region will face a unique set of concerns in its energy sector development due to the dissimilarity in size, energy resource endowments and history of energy use. Depending on their policy choices, Latin American countries will face different advantages or constraints in achieving their individual development goals during the 1990s.

\section{RECENT DEVELOPMENTS IN LATIN AMERICA IMPACTING PETROLEUM INVESTMENTS}

Steady ongoing political and economic changes in Latin America, coupled with a renewed hemispheric drive toward more open and reciprocal trade and investment policies being pursued through various regional free trade agreements, present significant opportunities for growth and investment for international petroleum companies within the context of longstanding historical sovereign principles. Characterized by liberalization and deregulation, including the privatization of numerous state-owned enterprises, these political and economic changes, if sustained, could attract substantial new investments in petroleum and natural resource projects in Latin America and help establish a business environment that promotes much greater economic growth and general prosperity.

As economies in Latin America grow, the demand for energy (electricity and fossil fuels) will expand at even higher rates. During the 1980s, in spite of a severe recession in Latin America, there was a continuous growth of crude oil consumption. The existence of policies that continue to limit access to potential crude oil and natural gas reserves and domestic and foreign markets; seek to control crude oil refined product prices and profit margins; subsidize public sector producers, petroleum products, and energy; or utilize taxes and economic sanctions to achieve foreign policy objectives, may significantly limit the progress to be made. Such impediments if not removed in 
a timely fashion will undoubtedly constitute a large competitive disadvantage for Latin American countries locally and regionally in the global marketplace.

Continued growth, competitiveness of Latin American countries and the need to ensure hemisphere energy security all require that Latin American governments formulate policies that attract investment from both international and domestic sources rather than increase indebtedness. An advantage of investments from the standpoint of the host country is that the risk is not borne by the government and its people but rather by the investor. In today's global economy the competition for capital is intense and, therefore, the policies must be competitive.

Since the petroleum sector typically carries high risks and is capital intensive, it requires investment policies that are transparent and firmly established in law. The sanctity of contracts must be strictly observed by both the government of the Latin American host country and private investors. An investment based on a contract often becomes uneconomical when the host government unilaterally changes the contract with the investor.

In addition, investors require policies that safeguard intellectual property, permit an attractive return on investment, allow for free repatriation of profits and dividends, allow for a pro-growth nondiscriminatory tax regime and provide for effective international dispute arbitration.

Investors in petroleum projects also require security under law, within historical principles, of the right to explore, develop and market the crude oil and natural gas produced. In addition, investors require access to domestic and international markets, transportation and distribution systems, and market-related prices, which are essential to maintain a competitive energy sector. Such conditions encourage continued investment and increase the likelihood of a fair return for all parties.

Increased investment induced by the establishment of more competitive investment terms would undoubtedly cause host countries in Latin America to directly benefit from increased domestic and export revenues, new business and employment opportunities, expanded domestic markets, and sustained economic growth. Ancillary benefits resulting from associations with first-rate international petroleum companies include access to advanced technologies, access to markets, high-quality competitively priced products, training of the local work force, development of infrastructure and a worldwide recognition of established investment policies.

The existence of long-term associations between host countries and private investors in petroleum projects can result in new opportunities in areas other than the exploration and production of hydrocarbons, such as in marketing petroleum products and the sale and transmission of natural gas. Venezuela by itself, as a major long-standing producer, is a natural area that should benefit from such long-term associations. Furthermore, long-term associations can help develop regional markets throughout Latin America. For example, in the Southern Cone there is a potential to export surplus Argentine and Bolivian gas to energy-importing countries Brazil, Chile, Paraguay and Uruguay. 
Another potential regional market that could benefit not only from long-term associations but also from investor access is the NAFTA. NAFTA offers an opportunity for the countries of that region to find new crude oil and natural gas reserves, expand production of existing reserves and develop markets for petroleum products.

Recent petroleum laws and agreements in Latin America are likely to give more leeway to the discretion of multinational petroleum companies - on the theory that those who spend their risk funds will, and should, know best how to spend these funds effectively; approval of operations is now often transformed into merely informing or consulting with the government, leaving most of the ultimate decisions to the private petroleum company. There are less issues where government consent is required usually those with a clear public policy content such as environment - and governments are under pressure to grant such consent according to already specified criteria within stipulated deadlines. A 1990s petroleum agreement in Latin America will thus likely reflect the spirit of de-regulation and de-bureaucratization; government prerogatives will be less, shorter and much more circumscribed than the 1970s model.

Government participation in petroleum ventures in Latin America is generally less pervasive, more gradual and optional and aiming less at the target of majority participation than at objectives such as participation in information, technology and obtaining additional fiscal participation in case of profitable ventures. State participation is usually assigned to the state petroleum companies and these have found it exceedingly difficult to finance their share of projects - essentially as non-operating partners. Mechanisms of financing such a share from subsequent production revenues have developed. While the prospectivity of an acreage may encourage companies to accept a privileged treatment for the state-owned petroleum company, such as exploration carry or other forms of carried, preferential entry and exit rights basically an extra payment for access to the resource - the general tendency towards treating state-owned petroleum companies more like commercial companies on an equal footing with private petroleum companies may lead to a further decline of such preferential treatment and have state-owned petroleum companies participate in exploration ventures like any other private petroleum company offered a farm-out. It is certainly debatable whether a government should try to obtain the price for its acreage by preferences for state companies or rather by other direct fiscal instruments.

There has been a distinct move, very much spearheaded in the major Latin American countries (Chile, Argentina, Bolivia, Mexico and Brazil) towards restructuring stateowned petroleum companies to make them less politicized, more commercially focused and accountable and more like private companies in terms of business focus, autonomy and competitiveness. Ultimately, partial privatization by expanding the capital base of state-owned petroleum companies through share flotation or full privatization could be the outcome of current government policies. The question is, whether or not countries heavily dependent on the development and sale of petroleum resources are ready to relax their control over resource industries by selling off to private and foreign interests, in one way or other, state-owned petroleum companies that are viewed as strategic as well as symbolic of national control over core industries. It is not surprising that privatization so far has not covered many key Latin American state-owned petroleum 
companies. The question, still unanswered, is whether the future inexorably points towards these giants in their own countries becoming privately owned, internationalized resource companies.

The gradual restructuring of state-owned petroleum companies and the relaxation of their exclusive hold over national acreage means that access to acreage may be obtained from the spoils left by liquidated or liquidating state petroleum companies without imposed association with the state petroleum company (e.g. YPF in Argentina). Getting new land for petroleum exploration more often than not goes not through traditional application of petroleum law but through picking up unused or inefficiently used properties from the state-owned petroleum companies.

\section{LEGAL FRAMEWORK FOR UPSTREAM PETROLEUM INVESTMENTS IN LATIN AMERICA}

Ownership of petroleum rights in the international arena including Latin America is almost always vested in the government. This public ownership regime has resulted, in most cases, from nationalistic desires to control the development and disposition of all strategic or vital resources within the country. The economic significance of petroleum, which in many countries is far and away the singularly most important source of income, ensured the selection of the public ownership regime.

Typically in Latin America, the foundation of the public ownership regime for petroleum is the country's petroleum law which sets forth the manner in which petroleum exploration and development rights can be granted to foreign petroleum companies. A Latin American country's petroleum law will typically specify:

(1) the state agency (Ministry of Energy, Council of Ministers, President, state oil company, etc.) charged with responsibility for administering petroleum rights, granting petroleum development rights to foreign petroleum companies, and monitoring the exploration for and development of petroleum reserves;

(2) the governmental approvals required for the grant of petroleum development rights;

(3) the method (competitive bidding, individual negotiations, etc.) to be used in granting petroleum rights;

(4) some or all of the rights of the country in regard to management of the petroleum operations and the receipt of royalty or other remuneration; and

(5) some or all of the rights granted to and the obligations to be assumed by the foreign petroleum company acquiring the petroleum development rights in the exploration agreements. 


\section{REVIEW OF KEY ISSUES IN PETROLEUM AGREEMENTS WITH LATIN AMERICAN FOREIGN HOST GOVERNMENTS}

The type of agreement chosen for the joint venture is not necessarily in itself desirable nor undesirable to either party. What really is important are the terms and conditions of the joint venture agreement and how they may impact on either the host government or the domestic company. The key issues in the joint venture relationships between companies and governments can be divided into fiscal and operational issues and legal and issues. Neither division reflects comparative importance - many agreements fail because some key issues cannot be agreed on by the parties in the joint venture.

Petroleum company negotiators and attorneys need to understand key issues as a means to help the parties reach an agreement. The following issues are generally the basis on which a joint venture negotiation will either succeed or fail.

\section{A. FISCAL AND OPERATIONAL ISSUES}

There are important fiscal issues for a petroleum company going international relating to tax and royalty, signature bonuses, state participation, cost recovery and amortization, production splits and profit sharing, tax consolidation and operational issues in exploration and development, all of which will require much give and take by both parties for the joint venture to succeed.

\section{Signature Bonus}

An issue which the petroleum company and government encounter, usually at the start of negotiations, is the signature bonus. From the petroleum company's viewpoint, the signature bonus is a disincentive to an agreement. A signature bonus amounts to a cash requirement from the petroleum company at the time that the agreement is signed. The amount expended is treated as part of the exploration budget and, therefore, detracts from the total exploration effort.

\section{Production Bonus}

Production bonuses are arguably more useful and acceptable than signature bonuses to promote a joint venture. A production bonus amounts to a cash payment by the contractor at selected intervals during the productive life of a project. Usually the timing of this payment is associated with the achievement of some predetermined level of productive capacity. A production bonus at some level of production has a less negative impact on a petroleum company than does a signature bonus. The major element of risk has been eliminated once production begins and the present value impact is not as great. 


\section{State Participation}

The percentage of state participation and the need to "carry" the state in the exploration phase must be considered by a petroleum company in assessing a joint venture. If the profitability of a project is small and the state has a high percentage of participation and is carried, a petroleum company may not be able to justify the allocation of its human resources to the project. If a host government wants to promote the joint venture, it should structure its state company as a true commercial entity, with a reasonable participating percentage, which pays its way in exploration and assumes all risks in the joint venture.

\section{Cost Recovery and Amortization}

A petroleum company in a joint venture requires a significant portion of the revenue generated in the early years of production to recover costs. This is an incentive to the joint venture. This can be done by providing for a high percentage of cost recovery in production sharing contracts ("PSC") and for rapid amortization rates in tax/royalty agreements.

\section{Production Splits and Profit Sharing}

The production splits and profit sharing in the joint venture should be responsive to the profitability of the project so as to be equitable for both parties. The fiscal provisions must ensure profitability over a wide range of reserve sizes, costs and oil prices. While each petroleum company will, of course, develop its own standards to determine the economic viability of a project, the levels of production splits and profit sharing will play a critical part in determining the viability of a joint venture.

\section{Ring Fence and Tax Consolidation}

The absence of any "ring fence" provision in a joint venture agreement is an incentive for continued exploration once a petroleum company has established production in that country. Under tax consolidation provisions, investments made on any acreage in a country may be recovered against income from production from anywhere within the country. Cost recovery should at least be permissible for any investments and production within the same license.

\section{B. LEGAL AND CONTRACTUAL ISSUES}

Legal and contractual issues are important for a petroleum company to consider in joint ventures. The following are considered to be key legal and contractual issues.

\section{Stability of Contract}

Stability of contract is a major consideration in joint venture relationships with host governments. It is a provision that must be recognized and agreed to by the parties for any joint venture to be successful. The stability clause is essential to provide that the 
host government may not enact any legislation that conflicts with or changes the tax, royalty, fiscal or other provisions of the agreement to the detriment of the petroleum company.

\section{Arbitration}

It is important that the arbitration provision provides for arbitration to be "selfexecuting". It will take place regardless of the conduct of either party. This ensures that there can be no frustration of the arbitration process. Self-executing mechanisms are found in arbitration procedures provided by the International Chamber of Commerce, the World Bank arbitration scheme and other multi-national organization arbitration procedures. As to impartiality, there should be provisions for arbitration to take place in a neutral country and the arbitrators to be nationals of neutral countries.

\section{Exchange Provisions}

No restriction should be placed on the petroleum company to freely import or export funds resulting from the conduct of the joint venture operations. The petroleum company should also have the right to convert payments and sums in the host country into convertible currencies at market rates and should not be compelled to keep funds in local currency. In addition, for the joint venture to succeed, the petroleum company should have the right to freely import funds into the host country or to keep funds abroad which are to be used in petroleum operations.

\section{Control in Operation}

When the petroleum company is assuming the risk in the joint venture and is "carrying" the state company, the petroleum company should have control over operations. In all instances, control over operations in the joint venture will require strict adherence to all safety and environmental standards.

\section{Establishment of Norm Price}

Any price used as a basis for calculating tax, royalty or other payments to governments in the joint venture should be a market price, objectively ascertainable or a market price determined by a neutral third party. For example, if the host government has the unilateral power to fix a norm price, any price higher than the market price under PSCs would result in the petroleum company recovering a lesser amount of its costs and paying a larger amount in royalties.

\section{Assignment}

The petroleum company would like to have the right to assign its interest in the joint venture to third parties. Farmouts are an important element in joint venture operations. The host government would have the right to approve the assignee for its suitability as a participant but approval should not be unreasonably withheld. 


\section{Environmental Issues}

The increasing influence of environmental and other groups must be taken into account in the joint venture. Such organizations can exert considerable pressure on joint ventures to modify the manner in which they conduct operations. Both parties should understand the need under the joint venture to respond to these influences.

\section{Other Issues}

There are many other provisions - force majeure, consequential damages, applicable law, host government's tax legislation, joint and several liability, and others - which may have an important effect on whether a joint venture agreement is possible.

The best agreement is one that recognizes the common objectives and mutuality of interests of both parties and provides an appropriate commercial foundation within the context of the joint venture agreement. It is important in joint venture agreements to treat political and fiscal risks openly and clearly.

\section{A PETROLEUM COMPANY'S ENTRY INTO INTERNATIONAL OPERATIONS: INTERNAL PHASE}

A petroleum company, prior to deciding on entry into the international arena, must conduct an "in-house" analysis to determine where and how to invest internationally. If the company decides to invest in the international arena, it must then decide on the "external steps" it must take - that is, how to deal with the host government in order to make a deal and to achieve its objectives in the international arena.

Any good "in-house" analysis of a potential international petroleum project must consider in the preliminary overview the geological and strategic objectives the petroleum company will pursue and the countries and regions in which such objectives might possibly be achieved. This requires a study of the countries in which activities may be conducted and the following points:

(1) Which country provides the best rewards consistent with the geological prospectivity and amount of investment required?

(2) What are the terms and conditions of the petroleum legislation or model contract of the host government?

(3) What are the geological risks of discovering hydrocarbons in commercial quantities?

(4) What are the rates of return and net present values to the company under various scenarios and risk analysis techniques in the event of discovery of hydrocarbons? 
(5) What are the political risks of operations in the country? Does the host government have a record of unilateral action by expropriation or by changes in the anticipated economic benefits of the contract? Is insurance available from governmental agencies to provide against unilateral action and political risk? Will such risk insurance be available under all circumstances of the deal?

(6) Will requirements for training and employment of nationals at various levels of the operations be acceptable from the petroleum company's level of commitments?

(7) Is there a reasonable fiscal framework governing oil and gas exploration and production so that the petroleum company's objectives are met fairly and equitably?

(8) Is there access to production and reserves for the petroleum company's worldwide operations?

(9) Are there sufficient and prompt cost recovery arrangements?

(10) Are the rates of return and net present values commensurate with the level of the investment commitment and technical, economic and political risks?

(11) Is there a clear right to freely export petroleum in international market transactions?

(12) Is there a right of repatriation of earnings without restrictions?

(13) Is there a right of currency convertibility at realistic market rates?

(14) Will there be a right for the operator to have control over operations within the framework of the work commitments in the petroleum agreement and in the conservation, safety and environmental regulations both of the host country and the world community?

(15) Will there be impartiality and self-executing procedures in arbitration and dispute resolution provisions?

(16) Will the state oil company, if a participant, share the financial commitments required and, whenever feasible, the capital and risk burdens?

(17) And, of special importance, will there be provision for "stability" of the agreement and the host government's policies and attitudes with respect to foreign investors?

From the petroleum company's viewpoint, the above points will be the foundation for a successful petroleum agreement in its entry into international operations and the basis on which investments may be made worldwide in exploration, production and 
other oil-related agreements. Agreement on the above points could lead to successful first-time joint ventures in international petroleum projects by the petroleum company.

\section{OVERVIEW OF TYPES OF INTERNATIONAL PETROLEUM EXPLORATION AND DEVELOPMENT AGREEMENTS CURRENTLY IN USE IN PETROLEUM PRODUCING AND EXPORTING COUNTRIES}

\section{A. INTRODUCTION}

The three major types of exploration and production agreements currently in use in the international petroleum industry are: the concession agreement, the production sharing agreement and the service agreement.

Some of the most important distinguishing features of each of these types of exploration agreements are briefly discussed below. However, it should be pointed out that the most commonly encountered exploration agreements in use today in Latin America and elsewhere in the world are "hybrids" mixing distinguishing features from one or more of the basic exploration agreements. It should also be pointed out that often more than one of the basic exploration agreements may be in use in a given country at any time.

The basic conceptual components which are common to each of the basic exploration agreements are:

(1) Exclusive Interests to Explore and Exploit an Area. The exploration agreement will define the contract area subject to the agreement, the term of the grant, the relinquishment obligations and the other rights of the petroleum company within the contract area.

(2) Technology and Financing. The exploration agreement will typically provide that the foreign petroleum company will be responsible for providing the technology and financing to conduct all petroleum operations. A minimum work program will customarily be specified. Also, obligations for training and transferring technology to nationals will be specified.

(3) Management of Petroleum Operations. While the foreign petroleum company is generally designated as the operator of petroleum exploration and development operations, the exploration agreement will spell out the degree of oversight or control that can be asserted by the host country or the state-owned petroleum company in the course of such petroleum operations.

(4) Division of Production. The exploration agreement will specify the methodology for dividing production between the host country and the foreign petroleum company. Provisions will also be included to allow the foreign petroleum company to freely export its share of crude oil production and/or repatriate its share of funds received under the exploration agreement. 
(5) Dispute Resolution. The exploration agreement will specify the manner in which disputes between the host country and the foreign petroleum company will be resolved. This generally entails international arbitration in most areas of the world.

(6) Local Issues. The exploration agreement will contain provisions to address "local issues" such as any preference in the procurement of local goods and services and/or preference for locals in the hiring of personnel.

The chief differences among the three basic exploration agreements lie in the method of compensation or remuneration (i.e. the way in which produced petroleum is divided between the host country and the petroleum company) and in the degree of management oversight reserved to the host country (or its state oil company).

\section{B. SPECIFIC TYPES OF INTERNATIONAL EXPLORATION AGREEMENTS}

\section{Concession Agreements}

The concession agreement is the oldest of the international exploration agreements and still the most commonly encountered type of exploration agreement in the international arena.

A concession agreement is a grant of petroleum exploration and/or production rights from a sovereign to a petroleum company within a specified area and for a specified term in exchange for the undertaking of the petroleum company to provide the financing of all costs and the payment of a royalty and income tax to the sovereign.

A concession agreement is often labelled as a "lease", "license" or "permit" and generally forms part of a complete legislative enactment on the subject and the relationship created. Absent a legislative structure, such as in many of the Gulf states in the Middle East, the essence of the concession agreement is embodied in a written agreement. The following countries are representative of the countries which use the concession agreement or a hybridized concession agreement: United States, United Kingdom, Norway, Australia, Egypt, Dubai and Thailand.

The early concession agreements have been the subject of intense criticism because of the vast areas of land (often entire countries) covered by the concession grants, the long time periods of the concession grant, the lack of governmental management or control over petroleum operations, and the financial disadvantages of the royalty structures under the concession grants.

Modern concession agreements have overcome these criticisms by restricting the grant to a designated area, often with periodic relinquishment obligations, for a limited period of years and subject to specified geophysical or drilling work obligations. The compensation to the sovereign is still structured in the form of royalty and tax payments but such compensation is now set on a more favourable basis to the sovereign, usually based on the world market prices received for petroleum production. 


\section{The Production Sharing Contract}

The production sharing contract was developed in the early 1960 s as a result of the dissatisfaction of certain countries with the then existing concession agreements. This form of exploration agreement was designed to increase the government's management control over the petroleum company's petroleum operations and to more equitably balance (to the host country's advantage) the compensation afforded for petroleum development.

The key elements of any production sharing contract are: oversight and management of petroleum operations by the state oil company; specific geophysical and drilling work commitments; payment of all costs of exploration and development by the foreign petroleum company; recovery of costs incurred by the petroleum company from production; "sharing" of production in excess of costs between the petroleum company, the state oil company and the government; and payment by the petroleum company of income taxes and certain other taxes in the foreign country. Countries such as Indonesia, Nigeria, Egypt and Russia have utilized the production sharing contract on a regular basis.

\section{The Service Agreement}

There are two general types of service agreements used in the international petroleum industry differentiated by whether the private foreign petroleum company has assumed exploration "risks".

The type of arrangement where a petroleum company does not undertake any exploration "risk" is essentially the same as any other contract for services. The petroleum company performs certain services and is paid a fee measured by the contractually agreed value of such services. Under such non-risk service agreements, the petroleum company is the same as any other services contractor to the state-owned petroleum company.

In a risk service agreement, the petroleum company undertakes to perform and pay the costs for certain defined exploration activities within a defined contract area during a specified term under the direction of the state-owned petroleum company. If no petroleum is discovered, the petroleum company bears the risk of the exploration expenses. If petroleum is discovered, the petroleum company is obligated to pay to develop the petroleum and is entitled to receive reimbursement of its exploration and development costs (plus interest in some circumstances) and a "risk" or "service" fee from the petroleum produced. The reimbursement of costs and the risk or service fee, which is calculated based on the recoverable reserves of petroleum, may be paid in cash or in kind.

Under the risk service agreement, the state-owned petroleum company maintains a very high degree of control over all facets of petroleum operations. Indeed, in some risk service agreements, the state-owned petroleum company actually takes over operations from the private petroleum company either prior to the commencement of 
or immediately after the completion of development. Additionally, the private petroleum company does not share in production, rather it receives reimbursement of its costs and a risk fee. These are the two characteristics which distinguish this type of international exploration agreement.

Some form of risk service agreement is widely used in Latin America, with the following countries being representative of those using some form of exploration agreement: Venezuela, Argentina, Brazil, Colombia, Ecuador, Peru, Bolivia and Mexico.

As previously noted, the concession agreement, production sharing contract or service agreement define and regulate the rights, duties and obligations between the host country or the state-owned petroleum company on the one side, and the contractor, which may include one or more private petroleum companies, on the other side. For the most part, the concession agreement, production sharing contract or service agreement regards the contractor group unilaterally. This approach ensures "single point accountability" of the contractor group to the host country or state-owned petroleum company for the exploration and exploitation obligations expressed in the concession agreement, production sharing contract or service agreement.

\section{THE ROLE OF LEGAL ADVISORS IN ASSISTING INTERNATIONAL PETROLEUM COMPANIES IN MAKING SUCCESSFUL FOREIGN INVESTMENTS IN LATIN AMERICA}

Good, high quality legal advisors can be extremely helpful in facilitating investments by their petroleum company clients in Latin America. Attorneys can play a significant part in identifying and managing legal risks of concern to such companies and their outside investors in upstream oil and gas ventures.

Legal advisors in the international energy project area are like tailors. When a tailor gets an order for a suit he takes measurements and then cuts and fits the suit to meet the particular needs and requirements of his customer.

Legal advisors are similar. Once a client has explained a proposed business deal, the legal advisor must: (1) identify the legal issues involved; (2) find structural solutions to manage those issues; and (3) draft the agreements to implement those solutions. Like a tailor, the legal advisor's job is to cut and fit legal solutions to the issues presented by the transaction or project.

The legal advisor's first task, then, is to identify the legal issues raised in connection with a proposed project, particularly if it involves outside financing. Let us turn briefly to some of the legal issues that might affect a petroleum company involved in an upstream petroleum project in Latin America. For example, what governmental and regulatory approvals are necessary for the various aspects of the proposed transaction? How much time will it take to get the approvals and what conditions must be satisfied? What access to financial support from multi-lateral institutions is potentially available? Can profits be freely repatriated? The answers to questions such as these will shape the 
structure of the petroleum project and any potential outside financing. Because of the important political element in some of these questions, it is very helpful to have legal advisers who are familiar with the perspective of host governments and particularly with the sensitive political issues involved when industries move from public to private hands.

Another crucial task is identifying the legal risks a company and any international investors will need to assess in providing capital to fund petroleum projects. As the economists tell the investors, including private companies, an investor should only agree to provide capital on the expectation of earning an acceptable return on the capital in the future. That expectation rests on an assessment of the risks of the investment. If the risk is too great, the investor will not make the investment.

The assessment of legal risk always requires a careful examination of the laws and regulations affecting the investment. Experienced international oil and gas attorneys have a great deal of experience in understanding what laws and regulations will be of concern to multinational companies and international investors. For example, investors clearly need to understand the rules governing foreign investment. In addition, investors will want to evaluate the legal form their investment should take, such as a joint stock company or a joint venture arrangement in the case of equity investors, as well as what terms would apply to any oil and gas concessions or production sharing arrangements. Investors will also want to know who controls the legal rights over petroleum properties. Who owns the reserves? Where are the potential markets?

Laws and regulations affecting production will need to be understood. For example, equity investors including private oil and gas companies will be interested in environmental laws and any mandatory social benefits requirements for employees. What employment levels are expected? What rights do local workers have? Will there be any liability for environmental damage caused prior to the investment? What environmental requirements exist on abandonment of an oilfield?

Both debt and equity investors will want to understand in detail how taxes will affect their investment. Profit taxes, withholding taxes and any requirements for obtaining preferential tax treatment will be of major interest. Legal advisors can often be particularly useful in helping to develop tax regimes to encourage international investment.

Other rules that operate to reduce returns on investment will also be important to investors. Mandatory currency conversion and rules regarding repatriation of earnings are two examples.

Potential limitations on the transport of crude oil and natural gas to market will be viewed as significant. Examples include export quotas and the requirements for export licenses as well as the legal uncertainties surrounding the operation of essential pipelines. 
At a more basic level, investors will need to judge the risks inherent in legal systems in the midst of change. Legal uncertainty increases investment risk, which raises the cost of capital or renders it unavailable. In a sense, it is perhaps more important that the rules be set and predictable than advantageous. Consistent treatment of similar cases, fundamental fairness and the avoidance of abrupt changes in the law or the application of the law are key attributes of any legal system that seeks to foster investment from the international financial community.

In particular, every investment involves a set of legal rights that investors view as basic. For instance, the ability to enforce contractual rights is fundamental. If investors perceive unusual risks of enforcement of contractual rights they will look to structural means of assuring repayment, such as payments by off-take purchasers in offshore accounts for the benefit of international lenders, a standard technique that was used in the financing of a project in the Oso field in Nigeria.

In addition, there are a number of other issues which, although they mainly involve business risks, require an attorney's attention because they are traditionally managed through the legal structuring of a financing transaction. The kinds of business risks that may become issues in an international petroleum project include market risks over the price of crude oil and transportation, completion risk, reserve risk, political risk and interest rate and currency risk. Typically, these risks are borne in different degrees by those interested in the company or project to be financed, such as sponsors, suppliers, purchasers, lenders, insurers, governments, export credit agencies and multi-lateral institutions, like the World Bank. Frequently, these risks are allocated by contract through negotiations in which legal advisors play an important role.

Of course, in many equity investments contractual allocation of risk is not required. On the other hand, it is the fundamental basis of project finance transactions, which ideally are structured so that risks are allocated to the parties best suited to bear them.

To take a typical example, in a project financing it would not be unusual for market risk to be dealt with by long-term, firm purchase contracts and transportation agreements, with careful provisions regarding price. Completion risk is often handled through construction contracts and sponsor agreements to fund cost overruns. Political risk frequently can be allocated, at least in part, to specialist insurers, governments or multi-lateral institutions. Interest rate and currency risks can often be dealt with through various hedging devices.

Whatever type of financing transaction is proposed - equity, debt or a combination of both - the terms of the investment must be carefully negotiated and documented. This is the stage at which the legal advisors for the various parties should be significantly involved, although ideally legal advisors to a client looking to raise capital would be involved with a proposal from the outset. Usually, detailed term sheets are prepared summarizing the transactions so that basic agreements regarding structure can be reached efficiently. Frequently, an offering document is prepared describing the company or project and the details of the proposed investment. During this stage it is 
important for the legal advisors to a company seeking financing to keep the basic structure as straightforward as possible and to maintain control of the process.

International financings are by nature complex and grow in complexity as additional parties become involved. All too often, financings that start out with complicated structures require costly and time-consuming restructuring.

Generally, it is best to stick to familiar financing structures, adapted as appropriate to the particular requirements of the transaction. Familiar structures are normally much more easily financeable than unusual and unfamiliar structures. That having been said, in risky financings particularly, there is almost always the need for creativity and flexibility on the part of the legal advisors involved.

Obviously, concerns regarding ownership of property interests make financing petroleum projects in Latin America a creative challenge for legal advisors, particularly in light of the political risks investors perceive.

After the initial structuring of the transaction has been accomplished, legal advisors turn to drafting the contracts that will implement the structure and govern the investment relationships. Often these contracts are complicated, particularly if a number of different parties are involved in different capacities. Each party will normally have its own legal advisors, increasing the need for organization and management of the drafting process. During this stage the legal advisors to the company should play a central role in keeping the agreements consistent and the transaction on schedule.

The contracts are circulated for comments and negotiated until a final set of agreements has been reached. A great deal of care should be taken to be certain that the contracts are drafted so that the rights of the parties are clear. Ambiguities can later be the source of significant and costly disagreements.

Beyond the need for careful drafting and close negotiations of documents, financing in the international capital markets also involves tasks that are purely logistical but which often fall to the legal advisors to perform. In particular, the process of coordinating the production and execution of all necessary papers and dealing with the difficulties of international communications and transportation frequently call for great resourcefulness. It is the legal advisor's job, however, to make certain that the contracts accurately reflect the transaction and are properly authorized and signed so that the closing of the transaction proceeds smoothly and professionally and the toasts at the closing lunch can take place on time.

\section{SUMMARY}

It is always risky to predict the future since unpredictable events may enter the fray. However, based on current developments, it appears that three major developments will significantly influence future petroleum licensing and negotiating practices in Latin America and the rest of the world. 
First, the large potential of the ex-USSR, combined with the chaos and confusion likely to surround its association with western capital for quite some time, is likely to be a major focus for the world's petroleum industry.

Second, restructuring, privatization and internationalization of at least the advanced state-owned petroleum companies is likely to continue. One could expect major new entrants into the industry, much as with the entry of western Europe's state-owned petroleum companies in the 1950s and 1960s.

Third, the environment will continue to dominate government policies towards petroleum development. It is likely that hydrocarbons, natural gas in particular, contributing the least to currently perceived global concerns - greenhouse effect and global warming - will play a greater role to the detriment of more polluting minerals such as coal. Pollution taxes such as those now being introduced in the European Community will undoubtedly accelerate such tendencies.

The privatization of YPF Argentina ranks as one of the most extraordinarily successful political and economic turnarounds of our time. It has set a precedent that other countries (particularly in Latin America) will have to consider as they define their petroleum investment policies in the future. The circumstances in Argentina were unique, both in terms of the desperate need to abandon unsuccessful past policies and in terms of there being a national private sector to participate in the assets that were spun off. The financial benefits were enormous, while most of the perceived political benefits of a large domestic petroleum company run by and for Argentines were retained.

Venezuela has now recognized that the investment required to fully exploit its hydrocarbon resources just cannot feasibly be generated by PDVSA on its own, without some major changes to that institution. As a result, private investment is again finding its way back into the Venezuelan petroleum industry: into the Cristobal Colon LNG project, into heavy crude oil development projects and into the so-called marginal fields.

Bolivia and Peru are on the way towards privatization in different forms. Columbia's upstream and some downstream (natural gas) activities are already open to foreign investment. Brazil is reviewing its constitution and has been circling around the issue of the Petrobras Petroleum monopoly for some time. Although the Mexican constitution remains firm on the national monopoly of petroleum development, there are farreaching changes going on in Pemex, the final results of which are difficult to predict but which seem to point towards greater involvement of the private sector.

The current pace of activity in petroleum development in Latin America is a good reason for confidence about a bright future. There are, however, several obstacles that need to be considered. These include the fact that petroleum is generally "owned" by the state and there is not always a clear law or regulatory environment for reaching agreement or ensuring the durability of an agreement over the longer term, especially if the margins of profit become large. The traditions of state enterprise and organized 
labour may create excessive expectations in the minds of the local community for carrying the entire burden of community development including schools, roads and electricity.

Poverty and the tensions that lead to anarchy are ever-present in most of the countries of Latin America due to the centuries old tradition of control over the many by the few. Within this set of cultural problems, one will also see strong evidence of a lack of trust of business and business people, especially if they are multinationals the code word for "colonialism". Activism of liberals, both local and foreign, in a sincere effort to improve the lot of the majority can cause a great deal of trouble if the investing company is unable to convince people that their presence is in the best interests of the underclass.

In spite of these obstacles, current trends offer an unprecedented opportunity for the international oil industry and host governments in Latin America to cooperate to their mutual benefit. With flexibility on both sides, countries can attract investment and look forward to seeing their petroleum make increasing contributions to their economy, while private companies can maintain their capacity to be engines for growth, even in an environment of low prices. 